\title{
Practicalities and Complexities Surrounding Escape Occurrences in Ghana's Correctional centers for Children in Conflict with the Law
}

\author{
Dr. Ayete-Nyampong, Lilian \\ Commission on Human Rights and Administrative Justice, Head office, Accra.
}

\begin{abstract}
The escape of juvenile and young offenders from committal tends to challenge the logic of correctional institutions in Ghana. The occurrence of escapes suggests undisciplined and rebellious youngsters as well as reformers or detaining authorities who are incapable of ensuring that youngsters are confined for correction purposes.

This paper focuses on the escape occurrences surrounding a juvenile female offender namely, Afua. By dwelling on everyday subtleties in committal, the paper unearths nuanced practicalities that surround escapes occurrences such as enmeshed staff and inmate spheres. This paper therefore departs from dominant discourses surrounding escapes that focus either on punishing escapees or preventing escapes. Though the paper dwells on a singular case and does not lend itself to generalisations, it nevertheless provides useful insider insights on everyday detention life which are mostly invisible to the human rights monitor, practitioner or the public eye. I pay tribute to my research approach different from my practitioner approach, which largely contributed to unearthing such concealed practical details.
\end{abstract}

Discussions draw on empirical evidence stemming from participant observations, focus group discussions and interviews with staff and children in conflict with the law.

Keywords: Correctional centres, children in conflict with the law, staff, escapes, Ghana

\section{INTRODUCTION}

This paper draws on some findings of a sociological research conducted in correctional centres for children in conflict with the law in Ghana from 2008 to $2013^{\mathrm{i}}$. The term 'children in conflict with the law' is employed broadly by Ghana's Juvenile Justice Act to embrace both young and juvenile offenders. A juvenile offender is a child under the age of 18 who has been convicted of an offence. A young offender is someone who is 18 years or more but below 21 years and has been convicted of an offence. The Juvenile Justice Act does not set a lower level limit for a juvenile offender. This gap is however filled by Section 4 of the Criminal Code Amendment Act 554 of $1998{ }^{[1]}$ which sets the legal age of criminal accountability at 12 years.

\section{METHODS}

This paper focuses only on the Junior Correctional Center (JCC) for female offenders. The broader research on which the paper draws employed research methods such as narratives, participant observations, interviews and focus group discussions (FGDs). As part of this broader research, I conducted 185 interviews, 116 participant observations and held 30 focus group discussions at the JCC and the Senior Correctional Center (SCC). This ethnographic research was the first ever undertaken in correctional centres for juvenile and young offenders in Ghana that employed interviews and participant observations over a prolonged period. My research was not based on hypothesis testing but required that the research process and my research role be guided by emergent empirical data. This research approach, constituted a methodological shift from that of my employer, the Commission on Human Rights and Administrative Justice (CHRAJ). The latter employed structured questions which were prepared ahead of monitoring visits to detention institutions.

My ethnographic approach encouraged certain innovative methods. For instance, during the initial stages of field work, some detainees and staff would hardly speak to me. Even with the increased acquaintance that came with participant observation, not much changed. I got round this difficulty by 
innovating what I termed 'conversational interviews' [2:32], interviews that formed an integral part of participant observations. Consequently, people were more willing to chat and respond to questions while we engaged together in various activities such as dress making lessons and farm work.

Observations and conversational interviews yielded insights on the dynamics of escapes which were concealed from me during my involvement in more than a decade of visits to correctional institutions in Ghana ${ }^{[3]}$.

The prolonged period of observations, offered the opportunity to observe continuously the same or different situations pertaining to escapes in order to appreciate patterns and variations. Such continuous observations of escape incidents afforded a rich import of diversity of empirical data from which interpretative insights emerged.

\title{
3. FINDINGS
}

Correctional centres or detention institutions, many a time, endeavour to prudently handle escape information internally and do not always disclose such occurrences. During the period of my research, four out of eight girls in committal absconded more than once during their period of committal. One of the girls by name Akua for instance escaped four times and was recaptured, the fifth time when she escaped, it was for good ${ }^{[4]}$.

Youngsters cite various reasons for embarking on escapes. The majority of girls during focus group discussions (ibid) said they dreaded being locked up as punishment and so absconded in order to escape such punishment. Yaa escaped because she did not want her hair cut in compliance with the rules of the institution. Grace, in an interview said she escaped because she wanted to demonstrate her frustration to her father who was indebted to the centre and did not visit her often. She feared that the father's indebtedness meant that even when her discharge was due, the centre would further detain her until all debts were paid.

This paper draws on participant observations over a period of eighteen months and details various spontaneous narrations surrounding an escape incident involving Afua, a female young offender.

Afua at the age of fifteen was pregnant when committed to the JCC and eventually gave birth while in committal. She nursed the baby for some time after which to her dismay, the baby was transferred to a children's home. One morning while the girls were holding their morning lessons, I noticed that three out of eight girls, including Afua were missing. Upon enquiry the others said the girls had escaped. I could not speak further with them as lessons were in progress so I went to the office of the headmistress where I met her and other officers in a meeting. They asked whether I had heard what had happened and the head went ahead to narrate to me what had ensued:

\begin{abstract}
It was in the evening and the girls were watching television. Theresa, one of the girls, with a special case and the oldest among the girls who was inside the dormitory was invited by the other girls to join them watch a TV programme. Upon joining them, she changed the $\mathrm{TV}$ channel to a different programme to the dismay of the other girls. A squabble arose amongst them as a result and the girls began to beat up Theresa. Afua and Akua bit Theresa, leaving marks on her body. Even while Theresa was weak and crying in her room, Akua, still followed again and pulled her hair... [4:117].
\end{abstract}

The headmistress called Theresa in and showed the scars to me and said that she was receiving treatment at the hospital. Two weeks after the incident when Theresa was feeling better, I spoke with her. She confirmed the incident and also revealed some additional information about an officer who witnessed the assault incidence. Theresa narrated her side of the incident:

We were all watching television and I wanted the channel changed. Three of the girls by name Afua, Akua and Akpene got angry and did not allow me but I insisted and as a result Afua and Akua jumped on me and started beating me. Before this incident I had been beaten several times (many a time the other girls just looked on). All the girls with the exception of two had beaten me before. I usually get infuriated by comments that they make such as 'who is your father?' and 'who is your mother?' and so I also insult them. Sometimes an officer looks on while I am being beaten. This officer was the one to whom I was entrusted when I first arrived at the centre and so I visited her often and liked her very much. However, she leaked 
confidential information from the doctor about me and that made me very angry. [4:118]

At the meeting with staff, I asked why Afua who was nursing a three-month old baby should abscond. One of the officers at the meeting responded: 'Afua had already started showing signs of neglect, not feeding the baby and regularly shouting at the baby to keep quiet and to stop crying and she recently locked the baby in a cupboard and also put her in hot water' [4:119]. The head interjected: 'I had initiated processes to send the baby to the children's home' (ibid).

Other issues however surfaced in the course of the meeting when I asked why they thought Afua behaved the way she did. The head responded: 'Once, Afua had mentioned that the baby would rather die than be taken to a children's home'. (ibid). Thus the thought and the possible warning of sending the baby to the children home must have driven Afua to such acts of violence and the latter must have been a way of expressing her disgust and fear of being severed from her child.

Afua was re-captured and two weeks following the meeting, I asked to see Afua at the remand roomii. We however managed to enter safely and I spoke with Afua briefly. She said:

\begin{abstract}
I put the blame on Akua, who absconded with me as she advised me to do so. But I also decided to escape on account of previous happenings as I did not want to be in the remand cell after the quarrel that arose in the dorm and so I boarded a taxi and left, I did not pay the taxi driver... (ibid)
\end{abstract}

Two days later, I visited Afua again. She spoke further about the escape incident: 'I absconded because I feared to be on remand after the incident involving Theresa. I remember when I came newly, I was put on remand for seven months and I decided I was not going back there again'. [4:120]

Afua had possibly anticipated the repercussions of the incident and considering the punishment the incident was likely to attract she decided to escape, though the bait must have been the company Akua offered. However, a crucial issue for Afua seemed to be that her baby was to be sent to the children's home:

I was unhappy when I heard that the baby was to be sent to the children's home as I wanted to keep my baby. I actually had not planned to return. I hear that babies sent to the home were usually sold and I did not want that. (ibid)

According to the head, the girls' institution sometimes makes arrangements at the children's home for fosterage of babies of youngsters who are unable to provide the required care for their children, and that this arrangement is done with the consent of the mothers. Afua in anticipation of being put in a remand cell and her child being given away, began to exhibit aggressive and violent behavior.

In the remand room, Afua shared her frustrations regarding certain structural needs:

My father does not visit often; he has visited only once. Every month my father is expected to pay GHS 20.00 (US $\$ 5.00$ ) monthly to the centre, which he does not do. My boyfriend was also asked to clear hospital bills when I delivered but he has not done that. [4:120-121]

Thus, besides the fear of being put in a remand cell, Afua must have been needing visits from home.

Afua's baby was finally taken to the children's home. Regularly, I arranged meetings with the head and the assistant to discuss issues that had come up during my observations and interviews and I sought an opportunity to discuss Afua's release from the remand room as she had spent two months in isolation. In response to the question about the duration of time Afua had spent in isolation, and whether or not the institution was considering releasing Afua, the head said: 'Not immediately' [4:122-123]. I asked why they still wanted to keep her in the remand room and she said:

Afua's presence in the remand room served as a check on newly admitted girls as such girls are usually unstable. Currently there are two new comers and they have already started tampering with the windows and have even broken the ball in the cistern and so the toilet can no longer flush. Afua's presence therefore acts as a positive impact on newly admitted girls. Afua partakes of all activities organized for the other girls and only comes to sleep in the cell in the evening. The presence of an older one always helps them to settle. (ibid) 
Whereas Afua must have construed her isolation as punishment for absconding and expected a release from the remand, the institution's attention had shifted from punishment to a supportive function. Afua's presence was now being employed to demotivate newly admitted inmates to escape; this new intention was however unknown to Afua.

Two weeks following a staff meeting that discussed the escape incident of the girls, one of the senior officers, said to me: The head insulted and cursed one of the girls and that must have infuriated the girls and contributed to their escape. The head does not seem interested in bringing back Akua who absconded along with Afua. Another officer also shared her views: 'Akua wrote a very nasty latter to the head when she was about to abscond and the head also thinks that this notorious girl seems to have a negative influence on the others' (ibid)

In fact, Akua and the other girl who absconded were never recovered. While Akua managed to escape with impunity, Afua was recaptured and subjected to severe punishment. About a month later, I had also observed that Afua acted quite violently while working on the farm one evening with the girls:

\begin{abstract}
Afua wore a frown while she weeded. She picked up a big stick so I said to her to be careful and then the captain said to me that she dared not hit her. Soon one of the senior officers joined us with her granddaughter; the latter was playing with a stick. Afua immediately lifted the little girl, took the stick from her and forcefully held her tight in the presence of the grandmother and another teacher who was also with us on the farm. The little girl cried out loud but Afua continued to hold on to her; eventually she let go. [4:124]
\end{abstract}

Midway through the year, Afua was finally released from isolation but was replaced by another girl, who also absconded and was sent to the remand room. Following her release, Afua had become generally uninterested in most activities and seldom participated in lessons. When she did participate, it was with little enthusiasm: In December 2010, Afua escaped again. Like the other girls, Afua seemed to have escaped for good as she had not been recovered until September 2011 when I last visited the centre.

\title{
4. Discussions: Practicalities that ChaRacterise esCaPes OCCURRENCES
}

\subsection{Low Fencing Tends to Defeat the Logic of Custody}

All correctional centres for young and juvenile offenders in Ghana seeking to project an image of correction are devoid of high walls. Low fencing walls, according to officers, symbolically send the message that youngsters are in a correctional centre or at a school and not entirely cut off from the outside world.

Low walls, however, pose a security challenge for staff as shared by some officers in a focus group discussion: 'The walls are so low. Some time ago, Yaa and some other girls jumped the wall at the side of the plantation. In fact, the walls are too low and this does not help us at all. [4:114]. Thus the physical structure of correctional centres according to officers is an invitation to abscond and tends to defeat the key function of prison officers, who seek to ensure that youngsters do not abscond but are held in custody for correction purposes.

\subsection{Reinforcement of Totalistic Measures}

During the occurrence of an escape, security and monitoring measures are tightened. Outdoor activities as well as educational lessons are curtailed or brought to a halt and young people are kept behind doors longer than usual. I observed that when escapes occur, the JCC tightens security and monitoring measures and youngsters training opportunities are restricted. Generally, escapes symbolically reassert an imagined total institution ${ }^{[5]}$.

Foregoing accounts of Afua however show that such stringent measures sometimes rather motivated and incited youngsters to rebel and subsequently abscond. Officers severally remarked during meetings and one on one interviews that youngsters deliberately did not listen to them, despite the measures they employed. Whereas officers were determined to employ more repressive and stringent measures to ensure youngsters were compliant, the reinforcement of such totalistic measures rather sparked off a cycle of escape incidents.

I also observed that whereas escapes symbolically reassert an imagined total institution and close up confinement space, they also open up private and social spaces for offstage chat, power and interest contestations, which break the monotony and sameness that characterize detention life. Almost 
everyone from the officer in charge through the various levels of officers to youngsters have some information to offer as an explanation, either directly or remotely related to an escape occurrence as depicted in Afua's case.

\title{
4.3. Violence and Enmeshed Spheres
}

Escapes in confinement life tends to be organized around the anticipation and occurrence of violence. Whereas youngsters may possess a history of violence stemming from their past prior to committal, happenings such as squabbles, fights and violent acts easily arise when various interests clash.

Perspectives on violence such as inter inmate and inmate-kin violence as well as staff inmate and staff acquiesced violence, are seldom exposed to the public eye. In fact, these perspectives were concealed from me despite years of being involved in monitoring the human rights situation in prisons and correctional centres. Whereas questionnaire employed by the CHRAJ's human rights monitors in correctional centres in Ghana have in the past sought information on violence, responses usually have had little or no indications of violence. I as well as other monitors may have been blinded to such views possibly due to the structured method of visits and the brief duration of such visits, ${ }^{[3]}$. Attempts to gain insight into such acts of violence in detention institutions without engaging over some period of time with the everyday relational confinement life may therefore conceal such confinement practicalities.

The anticipation of escapes by inmates invites stringent and sometimes brute reaction from staff. Such anticipation of violence surrounding escapes, is not limited to the dichotomy of staff dominance and inmate resistance or submission, but is situated within the relational encounters between inmatestaff, inmate-inmate and inmate-kin relationships.

Enmeshed encounters between inmate-staff or practices that entangle the official and the private as well as inmate and officer spheres usually characterise confinement life. As part of Afua's escape incident, reference was made to Theresa, who was maltreated by Afua and other female youngsters. In her story, Theresa alleged that one of the officers usually looked on while she was being beaten. On the same day that I spoke to Theresa, I also spoke to this officer. I asked about Theresa's background and why she was admitted to the centre as her case was usually referred to by officers as a special case. The officer in question responded:

\begin{abstract}
Theresa was a special case recommended to the centre on the basis of her quick temper due to a surgical operation she had undergone. She therefore shared one of the dorms with the female juvenile offenders. The doctor spoke to me upon her arrival and asked that I should ensure she was well taken care of. I tried to provide as much support as possible for her. She got a job in a nearby chop bar and usually brought some food along to my children in the evening. She tried to entice my children with food anytime she came and the door was locked so that the children would open the door for her. [4:126]
\end{abstract}

The officer's intention to protect Theresa was however short lived. She continued:

\begin{abstract}
One evening when I was about to enter the girl's dormitory (dorm), I realized that the dorm keys were not being handled properly and so I warned my children not to take food from Theresa any longer as this will stop her from coming to demand the key. I also warned Theresa not to provide the children with food any longer. This however did not go down well with Theresa and so one evening she came to the door with a bowl of food and one of my children told her to go back. When I questioned why she should still bring food to the children, she said she offered them food because they begged for it. While I spoke with her, she became very angry and hurled insults at me. She dared me to draw closer if indeed I was a lady. On hearing this, I no longer could control myself and I beat her up mercilessly. (ibid)
\end{abstract}

Other enmeshed spheres were observed at the JCC. A female officer spoke about a female youngster whom she had taken as her daughter but later got disappointed 'I took Tina, as my daughter, she ate in my house and did almost everything as my daughter and then she betrayed my trust and absconded Officer'. [4:104] . 
Thus, confinement life may not always characterised by a marked boundary between the private and the official ${ }^{[7]}$ but by entangled and fluid boundaries. In most correctional centres in Ghana, youngsters benefit from kind acts and are sometimes treated like the children of officers as was the case of Tina and Theresa. While officers expect that youngsters who benefit from such acts will be compliant, and not abscond, sometimes such trust is betrayed, resulting in repercussions for both officers and youngsters. Such forms of permeable boundaries between officers and inmates are characterised by informal institutional practices such as in the case of Theresa who was allowed to keep dormitory keys on the basis of friendly relationship with staff.

The concept of entanglement as exhibited in the above mundane and intimate social interactions suggest a loose and episodic mesh of social relations that are mutually supportive and interdependent ${ }^{[2]}$. Such a mesh of interactions is not akin to a trap or a tangle from which one cannot free oneself; they are characterized by negotiations and connote some degree of symmetry but also hierarchical differences. Arce\& Long ${ }^{[8]}$, make similar reference to entanglements of social relationships. They write of the notion of interface as entailing social relations that are always on the move and characterized by negotiations. The intricacies of entangled and informal interfaces that surround escapes transcend a predictable step by step or linear pathway characterized by disciplinary measures that deter youngsters from absconding. Whereas such informality and entanglements are usually exhibited off stage and rarely meet the official and public eye, they nevertheless contribute vitally to keeping up an image of a correctional center that is in charge and guarantees safety and security.

Hidden aspects of confinement life such as fluid boundaries and seeming informal institutional practices observed at JCC are therefore not viewed as being necessarily negative or as a contravention of institutional rules. Staff and inmates manage to circumvent, through negotiations, the gap between normative institutional or human rights principles of correction as well as what pertains in practice, as exemplified in Afua and Theresa's cases. Martin, ${ }^{[9,10]}$ in a similar observation in Ugandan prisons makes reference to polyvalence of human rights. He discusses how prison management in Ugandan prisons administers corporal punishment in seeming contravention of human rights principles. Officers in Ugandan prisons, according to Martin, circumvent such discrepancy and inconsistency by adapting corporal punishment and labelling it reasonable caning, thereby distinguishing it from torture. I liken such adaptations to Olivier de Sardan's practical norms ${ }^{[11]}$ that necessitate the negotiation of boundaries so as to keep up the appearance of a well-governed institution. Such negotiations are many a time relegated to offstage and are not easily observable by the public eye or by the human rights monitor ${ }^{[2,4]}$

The entanglement between the official and the private, or the formal and the informal, should however not be viewed as limited to only the African context. Crawley, ${ }^{[12]}$ in an ethnographic research in the United Kingdom, makes similar reference to "The Public and Private lives of Prison Officers". Similarly Jewkes and Johnstone ${ }^{[13]}$ in citing Mathieson ${ }^{[14]}$ in a research in Norwegian Prisons, observed that forms of official power are born of both formal and informal institutional practices. According to them, the actions by prison officers which impinge directly on the everyday lives and well-being of inmates though are officially sanctioned, yet are informal and unpredictable ${ }^{[13]}$

\section{CONCLUSION}

The ethnographic evidence presented by this paper has established that escape occurrences in correctional centres are not only about punishing youngsters who escape. On the contrary, everyday complexities of confinement are characterized by entangled relationships and nuances which invite escapes and vice versa. Discussions have accorded recognition to the importance of the social worlds of young offenders and how such youngsters do manage to circumvent detention barriers. By dwelling on the everyday life of confined children, the research offers empirical data that is complementary to literature on African youth as social actors mostly preoccupied with 'free youth' in contexts of war, conflict and violence. This paper challenges the notion that children such as Afua and Theresa are incapable of negotiating the boundaries of confinement seemingly imposed on them. It portrays children and young people in Ghana who have been lawfully deprived of their liberty but not of their agency to actively engage in shaping their everyday life conditions.

I pay tribute to a research process and an ethno-inductive approach characterised by serendipity that brought the theme of escapes to the fore. This is because escapes did not surface during monitoring visits as a practitioner neither did it constitute one of the themes I intended to research. Whereas generalisations could not be drawn on the basis of such a small scale study, foregoing discussions have depicted a number of interpretative insights useful for scientific and societal relevance. 
By turning the gaze from dominant discourses on African prisons characterised by legalistic, human rights and criminal justice perspectives, to a sociological viewpoint, the paper contributes usefulinsider perspectives that complement such prison discourses in Africa.

\section{REFERENCES}

[1] GOG, The 1998 Criminal Code Amendment Act (554) of Ghana. Government of Ghana: Accra, 1998.

[2] Author, Entangled Governance Practices and the Illusion of Producing Compliant Inmates in Correctional Centres for Juvenile and Young Offenders in Ghana. Prison Service Journal: Everyday Prison Governance in Africa 2014, (214), 27-32.

[3] CHRAJ, Annual Reports of the Commission on Human Rights and Administrative Justice. CHRAJ: Accra, Ghana, 1986-2010.

[4] Author. Entangled Realities and Underlife of a Total Institution. Wageningen University Wageningen, https://www.wageningenur.nl/.../, 2013.

[5] Bandyopadhyay, M.; Jefferson, A. M., Entangled Interactions: Prisoner-Staff Relations in India and Sierra Leone. In Dissecting the Non-Western Prison. Global Prisons Research Network (GPRN) Workshop, hosted by Netherlands Institute for the Study of Crime and Law Enforcement (NSCR), Amsterdam, Amsterdam, 2010.

[6] Hammersely, M.; Atkinson, P., Ethnography. Principles in Practice: Third Edition. Routledge: London, 2007.

[7] Goffman, E., Asylums: Essays on the Social Situation of Mental Patients and other Inmates. Penguin Hammondsworth, 1968.

[8] Arce, A.; Long, N., Forging a New Anthropology of Development: Common Ground and Contentious Issues Karthala: Paris, 2007.

[9] Martin, T., Reasonable Caning and Human Rights. In "Dissecting the 'non-western' prison" Global Prisons Research Network (GPRN) Workshop, hosted by Netherlands Institute for the Study of Crime and Law Enforcement (NSCR), Amsterdam, Amsterdam, 2010; pp 1-3 December.

[10] Martin, T., Human Rights in Ugandan Prisons In International Symposium on Prison Ethnography Milton Keynes, London, 2012.

[11] Olivier de Sardan, J. P., A Moral Economy of Corruption in Africa? The Journal of Modern African Studies The Journal of Modern African Studies 1977, 37 (1), 25-52.

[12] Crawley, E., Doing Prison Work: the Public and Private Lives of Prison Officers. In Prison Readings. A Critical Introduction to Prisons and Imprisonment, Jewkes, Y.; Johnstone, H., Eds. Willan: US and Canada, 2006.

[13] Jewkes, Y.; Johnstone, H., Prison Readings. A Critical Introduction to Prisons and Imprisonment. Jewkes, Y.; Johnstone, H., Eds. Willan Publishing: US and Canada, 2006.

[14] Mathiesen, T., The Defences of the Weak: A Sociological Study of a Norwegian Correctional Institution. In Prisons Readings. A Critical Introduction to Prisons and Imprisonment, Johnston, Y. J. a. H., Ed. Willan publishing: US and Canada, 2006

\footnotetext{
' This paper is based on a PhD research undertaken from 2008 to 2013, at the Wageningen University, the Netherlands. The researcher acknowledges the supervisory support for the $\mathrm{PhD}$ research of Promotor, Prof. dr. L. E. Visser and Co-Promotor, Dr. R.E. Gigengack both of the Wageningen University.

ii The remand for females is a one room commonly labelled 'remand'. This room performs a multi-function as it houses youngsters awaiting trial, newly committed youngsters and those in committal who as a result of punishment are detained.
} 